\title{
The value of a conscious patient in the intensive care management of tetanus - maximizing magnesium and minimizing midazolam
}

\author{
D Attygalle ${ }^{I}$ *N Rodrigo ${ }^{I}$ \\ Consultant Anaesthetist ${ }^{l}$, Colombo, Sri Lanka \\ *Corresponding author: dayanalini2@gmail.com
}

\begin{abstract}
The value of Mg therapy for patients with tetanus, which minimizes heavy sedation and paralysis in keeping with the goals of modern intensive care, is discussed.
\end{abstract}

Keywords: tetanus, magnesium therapy, sedation, intensive care

Times have changed - and more so in intensive care units (ICU). Gone are the days when patients were heavily sedated and paralysed. On the principle that it is "better to treat the disease than mask it", hypnotic sedation is minimized, with the goal of achieving a calm, lucid, pain free, interactive and co-operative patient, with reduced ICU stay, mortality and morbidity ${ }^{1,2}$. The goals we require for tetanus are no different ${ }^{3,4}$.

In the first half of the last century, tetanus patients were heavily sedated and nursed in quiet dark rooms.Mortality was high (30-70\%), deaths being due to spasms causing early respiratory failure, aspiration, and exhaustion. In the latter half, the scenario changed, with patients being paralysed and ventilated in ICU. Mortality rates dropped (12-23\%), deaths occurring later in the course of the disease due to sudden cardio-vascular events. Complications of prolonged ventilation with neuro-muscular blocking agents (such as ventilator acquired pneumonia, pulmonary embolism, atelectasis, sepsis, respiratory infections, malnutrition) also took their toll ${ }^{5}$.

Today in the 21st century new concepts of ICU management incorporate the PAD guidelines triad (Pain, Agitation, Delirium) and the ABCDE bundle (Awakening, Breathing, Coordination, Delirium monitoring, Exercise), the rationale being lighter sedation and earlier mobilization ${ }^{1}$.

\section{Traditional therapy with "heavy sedation"}

Benzodiazepines and opioids were given in large doses (diazepam $40-150 \mathrm{mg} /$ day) ${ }^{5}$ for the control of paroxysmal spasms and autonomic dysfunction of tetanus. Spasms were controlled, although the rigidity often persisted causing reduced chest compliance and hypoventilation requiring artificial ventilation. Sympathetic over-action (SOA) causing episodes of fluctuating tachycardia, labile hypertension, sweating and pyrexia needed additional beta blockade 5 . Parasympathetic overactivity caused profuse salivation and bronchial secretions. Accumulation, dependence and withdrawal agitation were added problems.

\section{Magnesium sulphate therapy}

$\mathrm{Mg}$ has the unique advantage of being able to reduce both spasms and autonomic dysfunction without sedation. By its central action it is a mild central depressant and an effective anticonvulsant. Peripherally, it competes with $\mathrm{Ca}$ ions for pre-junctional sites and inhibits release of acetyl choline. It reduces catecholamine release (from both adrenal medulla and adrenergic nerve endings), and receptor responsiveness. It competes with calcium in skeletal, smooth and cardiac muscle and is a generalized vasodilator, improving cerebral and renal blood flow. By antagonizing calcium metabolism, it causes muscle weakness (and even paralysis with toxic doses).

Thus, $\mathrm{MgSO}_{4}$ should be used as first line therapy in tetanus titrated to the clinical end points of control of spasms and rigidity sufficient to allow swallowing of saliva, mouth care and physiotherapy, while maintaining adequate respiration which should be closely monitored ${ }^{3,4}$. Clinicians should initially predict severity (Ablett classification) to individualize therapy. 
The loading dose is $5 \mathrm{~g}$ i.v. given over 20 minutes, and the maintenance dose $2 \mathrm{~g} / \mathrm{hr}$, increased by 0.5 $\mathrm{g} / \mathrm{hr}$ until spasms are relieved, or the patellar reflex disappears. The patellar reflex maybe an unreliable guide (unlike in pre-eclampsia) due to basal muscle rigidity, and is lost earlier in the elderly while within the therapeutic range ${ }^{3} . \mathrm{Mg}$ may safely be used for prolonged therapy as long as renal function is adequate.

\section{Need for ventilatory support}

Although in the majority of patients, $\mathrm{Mg}$ controls spasms and rigidity without the need for ventilator support or sedation ${ }^{3,6}$, the elderly, and those with respiratory complications, will often need ventilatory support. Also in very severe tetanus with resistant rigidity, spasms or hypertensive crises, where very high doses of $M g(4-5 g / h)$ are needed, respiratory depression may occur. Prolonged SOA in tetanus may sometimes end with profound hypotension and bradycardia, and $\mathrm{Mg}$ should then be discontinued or reduced, and spasms controlled with muscle relaxants and artificial ventilation ${ }^{3}$.

The effects of $\mathrm{Mg}$ are synergistic with other CNS depressants, cardiac depressants and neuromuscular blocking drugs and combinations should be used with caution. The danger is highlighted in the case report published in this journal. Thwaites ${ }^{7}$ showed that $\mathrm{Mg}$ therapy reduced the requirement of midazolam from 7.1 to $1.4 \mathrm{mg} / \mathrm{kg} /$ day and pipecuronium from 2.3 to $0 \mathrm{mg} / \mathrm{kg} /$ day to control spasms, and the need to treat SOA was 4.7 times less.

Overdose of $\mathrm{Mg}$ is easily detected clinically (warmth, flushing, double vision, slurred speech, muscle weakness). Toxic levels will cause severe cardiac and respiratory depression, but all effects are easily and immediately reversed with calcium gluconate i.v. ensuring safety.

\section{The awake patient}

With individualized infusion rates titrated to the changing needs of the tetanus patient, close clinical monitoring of the respiratory and cardiovascular systems, and sedation scoring, the goal of a conscious, cooperative, mobilized patient, tolerating enteral feeding should be achieved ${ }^{3}$.
Studies of outcomes in intensive care focus on mortality and duration of stay in ICU which give simple, concrete end points with finite numbers. Indeed most studies comparing $\mathrm{Mg}$ and traditional treatment conclude that $\mathrm{Mg}$ did not reduce mortality $^{8}$. Mortality depends on the severity of the disease, age, co-morbidity and stage of presentation which factors clinicians have no control over. It is time studies focused on patient comfort and quality of life during their stay in $\mathrm{ICU}^{9}$. It is surely not acceptable for a patient to lie comatose on mechanical ventilation for a month (masking all symptoms) and wake up from the nightmare frightened, confused, agitated, unable to write his own name (due to neuropathy and myopathy). It would be far better to aim for a conscious patient able to communicate his needs, fears and distress.It is time to supplement sedation scoring with a patient perception scoring where comfort, communication, natural sleep, etc are assessed. The advantages of having a conscious co-operative patient without the complications of heavy sedation and ventilation, are well known to nursing staff and relatives. It would also have an immense cost-benefit, especially in countries where tetanus is widely prevalent and should be the goal of all clinicians, specially for long term intensive care. $\mathrm{Mg}$ used as first line therapy (with additives as and when necessary) should help achieve this for tetanus patients.

\section{References}

1. Rowe K, Fletcher S. Sedation in the intensive care unit.CEACCP2008;8(2):50-55. http://dx.doi.org/10.1093/bjaceaccp/mkn005

2. Reade MC, Finfer S. Sedation and Delirium in the Intensive Care Unit N Engl J Med 2014; 370:444454.

3. Attygalle D, Rodrigo N. Magnesium as first line therapy in management of tetanus: a prospective study of 40 patients. Anaesthesia 2002, 57:811817.

http://dx.doi.org/10.1046/j.13652044.2002.02698_6.x

PMid:12133096

4. Attygalle $\mathrm{D}$, Rodrigo $\mathrm{N}$ : New trends in the management of tetanus. Expert Rev Anti Infect Ther 2004, 2:73-84. http://dx.doi.org/10.1586/14787210.2.1.73 PMid:15482173 
5. Udwadia TE, Lali A. Tetanus and its complications - Intensive care and management experience. Epidemiology and Infection. 1987; 99(3):1675-84. http://dx.doi.org/10.1017/S095026880006653X

6. Sikendar RA, Samad B, Ali S, et al. Post traumatic tetanus and role of magnesium sulphate. Journal Ayub Med Coll Abbottabad, Pakistan 2009;21(2): 132-5.

7. Thwaites CL, Yen LM, et al. Magnesium sulphate for treatment of severe tetanus: a randomised controlled trial. Lancet 2006; 368 (9545):1436-43. http://dx.doi.org/10.1016/S0140-6736(06)69444-0

8. Rodrigo C, Samarakoon L, Fernando SD, Rajapakse S. Review: A meta-analysis of magnesium for tetanus. Anaesthesia 2012; 67: 1370-4. http://dx.doi.org/10.1111/anae.12020

PMid:23033859 


\section{A PROTOCOL FOR THE USE OF MAGNESIUM AS THE FIRST LINE THERAPY FOR TETANUS}

This protocol is suitable for all patients diagnosed as tetanus having generalised muscle rigidity with or without spasms. Patients should be managed in a high dependency unit or ICU with immediate access to ventilatory support if needed.

\section{DIAGNOSIS (Ablett classification):}

\begin{tabular}{|c|c|}
\hline Grade & Clinical Features \\
\hline Grade 1 (mild) & Trismus with little or no dysphagia \\
\hline $\begin{array}{l}\text { Grade } 2 \\
\text { (moderate) }\end{array}$ & $\begin{array}{l}\text { Trismus, dysphagia, generalised } \\
\text { muscle rigidity with fleeting spasms, } \\
\text { not embarrassing respiration }\end{array}$ \\
\hline $\begin{array}{l}\text { Grade } 3 \mathrm{a} \\
\text { (severe) }\end{array}$ & $\begin{array}{l}\text { Trismus, marked dysphagia and } \\
\text { generalised muscle rigidity with } \\
\text { severe spasms, embarrassing } \\
\text { respiration }\end{array}$ \\
\hline $\begin{array}{l}\text { Grade } 3 b \\
\text { (very severe) }\end{array}$ & $\begin{array}{l}\text { All symptoms of Grade } 3 \text { a with } \\
\text { autonomic dysfunction }\end{array}$ \\
\hline
\end{tabular}

History of injury: Not always present since the injury is often trivial.

History of immunization - Tetanus cannot be excluded if immunization was 7 years prior.

Clinical features: Diagnosis is based on clinical features which have a typical progression of descending rigidity of muscles first affecting the cranial nerves (trismus, dysphagia) then the trunk (ophisthotonus, and generalised rigidity) and limbs.

Spasms occur with intervening rigidity.

Negative findings: no alteration of consciousness, or CSF biochemistry.

Spatula test is very specific for tetanus.
Ask the patient to open the mouth and insert a tongue depressor gently to touch the back of the pharynx. Clamping down on the blade is positive and a gag response negative for tetanus.

\section{ASSESSMENT OF SEVERITY}

Incubation period (period between injury and first symptom) - <14 days predicts severe tetanus (with spasms).

Onset time (period between first symptom and first spasm) $-<72$ hours predicts severe tetanus

Age $>60$ years and co- morbid factors increase the morbidity and mortality.

Grading: Ablett classification of severity

\section{MANAGEMENT}

\section{Neutralisation of the toxin:}

Antitoxin should be given as soon as the diagnosis is made to neutralise the circulating toxin before it enters the CNS via axons. It has no action once the toxin is bound to the nerves.

Anti-tetanus serum -ATS- 5000U IM and 5000U infiltrated around the wound (after Sensitivity Testing) or Human tetanus immunoglobulin 500IU IM Toxoid first dose as soon as the diagnosis is made, the second dose after one month and the third after 6 months. The disease does not confer immunity.

\section{Eradication of the organism}

Wide wound debridement under general anaesthesia

Antibiotics - Metronidazole 500mg i.v. 8 hourly for 10 days (Penicillin is contraindicated since it is a GABA antagonist and will potentiate the tetanus toxin) 


\section{Prevention of early complications}

Pulmonary aspiration and laryngeal obstruction are common causes of mortality in tetanus. Therefore, it is recommended that once the diagnosis is established, patient should be transferred to an ICU for monitoring and further care.

\section{On admission to the HDU or ICU}

\section{USE MAGNESIUM AS FIRST LINE THERAPY}

2. OMIT ALL SEDATIVES.

3. Maintain urine output at $>0.5 \mathrm{ml} . \mathrm{kg} .{ }^{-1} \mathrm{~h}^{-1}$

4. Start on i.v. fluids and do not feed till the airway is protected

\section{Airway protection}

Send the patient to the operating theatre for the following under general anaesthesia :

1) Urgent early tracheostomy within 24 hours of diagnosis in all patients predicted to develop moderate or severe tetanus.

2) Insert naso-gastric tube for feeding

3) Wide debridement of the wound

\section{Symptomatic management}

Control of rigidity and spasms with intravenous magnesium therapy

Loading dose: $5 \mathrm{~g}(80 \mathrm{mg} / \mathrm{kg})$ in $30 \mathrm{mins}$

Maintenance dose to be started with:

$<60$ years $-2 \mathrm{~g}$ per hour and $\geq 60$ years or moderate tetanus (no spasms) - 1g per hour Increments of $0.5 \mathrm{~g}(<60 \mathrm{yrs})$ or $0.25 \mathrm{~g}(\geq 60 \mathrm{yrs})$ six hourly (as serum level takes 6 hours to achieve new level) till spasms are controlled.

If spasms are very severe the higher increment doses can be used. Titrate to the control of spasms and a degree of rigidity acceptable to the patient.

If the patellar reflex is suppressed (when the rigidity is severe the patellar reflex often cannot be elicited) and spasms are not controlled continue to increase the dose but monitor respiration more carefully.

If spasms are uncontrolled with increasing respiratory rate $>30 / \mathrm{min}$ or tidal volume (TV) $<4 \mathrm{ml} / \mathrm{kg}$, support ventilation but continue to titrate the $\mathrm{Mg}$ dose to spasms. Give chest physiotherapy and suction clearance. Continue ventilator support.

Once spasms are controlled, attempt to reduce the dose by $0.25 \mathrm{~g} / \mathrm{hr}$, to ensure that the minimum effective dose is being given.

If hypotensive $(<80 \mathrm{mmHg}$ of systolic) or bradycardic (<40bpm) occur, STOP Mg.

If unresponsive, send blood for serum $\mathrm{Mg}^{2+}$, stop $\mathrm{Mg}$ therapy, and give $\mathrm{Ca}$ gluconate i.v. When stable continue at a lower dose.

Titration of $\mathrm{Mg}$ dose after loading dose

\begin{tabular}{|c|c|c|c|c|c|}
\hline Rigidity & Spasms & $\begin{array}{l}\text { Patella } \\
\text { reflex }\end{array}$ & TV & $\begin{array}{l}\mathrm{BP} \\
/ \mathrm{HR}\end{array}$ & Adjustment of dose \\
\hline $\begin{array}{l}++ \\
\text { After } \\
6 \mathrm{~h}\end{array}$ & $\begin{array}{l}++ \\
\text { After } \\
6 \mathrm{~h}\end{array}$ & + & Normal & $\begin{array}{l}\text { Norm } \\
\text { al }\end{array}$ & $\begin{array}{l}\text { Increase dose by } \\
0.25-0.5 \mathrm{~g} / \mathrm{h} \text {. } \\
\text { Monitor patella } \\
\text { reflex \& TV }\end{array}$ \\
\hline++ & + & - & Normal & $\begin{array}{l}\text { Norm } \\
\text { al }\end{array}$ & $\begin{array}{l}\text { Increase dose. } \\
\text { Monitor TV. } \\
\text { Prepare to support } \\
\text { ventilation }\end{array}$ \\
\hline+ & - & - & $\begin{array}{l}\text { Normal } \\
<4 \mathrm{ml} / \mathrm{kg}\end{array}$ & $\begin{array}{l}\text { Norm } \\
\text { al }\end{array}$ & $\begin{array}{l}\text { No support } \\
\text { Ventilator support- } \\
\text { SIMV/PS }\end{array}$ \\
\hline $\begin{array}{l}\text { Flaccid } \\
\text { Deep } \\
\text { sedated }\end{array}$ & - & - & $<4 \mathrm{ml} / \mathrm{kg}$ & LOW & $\begin{array}{l}\text { Reduce dose to } \\
2 \mathrm{~g} / \mathrm{h} \& \text { increase } \\
\text { again when spasm } \\
\text { commence. }\end{array}$ \\
\hline Flaccid & + & - & $<4 \mathrm{ml} / \mathrm{kg}$ & LOW & $\begin{array}{l}\text { Reduce dose \& } \\
\text { supplement with } \\
\text { relaxants }\end{array}$ \\
\hline
\end{tabular}




\section{Control of autonomic dysfunction}

Magnesium therapy as in above

If hypotensive $(<80 \mathrm{mmHg}$ systolic) stimulate patients, and if bradycardic (<40beats. $\mathrm{min}^{-1}$ ) give atropine.

If hypertensive ( $>170 \mathrm{mmHg}$ systolic) or tachycardic ( $>120$ beats. $\mathrm{min}^{-1}$ for $>1$ hour), give intravenous morphine.

\section{Sedatives and muscle relaxants}

In the event of maximum therapeutic range of $\mathrm{Mg}$ being reached or if $\mathrm{Mg}$ toxicity occurs, sedatives and neuromuscular blockers can be supplemented. As a sedative, Midazolam is preferred over diazepam.

\section{Monitor}

a. Hourly urine output $(>0.5 \mathrm{ml} / \mathrm{kg} / \mathrm{h})$

b. Ability to cough, patellar reflex, respiratory rate, tidal volume, arterial blood gases

c. Blood pressure, ECG, pulse oximetry

d. 12 lead ECG every third day and daily if serum $\mathrm{Mg}$ exceed therapeutic levels.

e. Chest X-ray after tracheostomy

f. Sedation score

g. Serum Mg daily, more frequently if signs of overdose are seen (normal range : $2-4 \mathrm{mmol} / \mathrm{l}$ )

h. Clinical signs of hypocalcaemia and serum calcium every third day

i. Serum electrolytes, albumin, blood sugar, urinary urea

The elderly group show signs of suppression of patellar reflex, respiratory inadequacy and even cardiac depression before $4 \mathrm{mmol} / \mathrm{l}$ are reached and therefore require support much earlier.

\section{Supportive therapy}

Tracheostomy care:

Maintain humidification

Suctioning can induce spasms. It may have to be done regularly if secretions are profuse.

Check the trancheostomy cuff pressure 8 hourly. Careful management of tracheostomy site by application of dry dressings 4 hourly.

\section{Adhere to ventilator care bundle}

Head up tilt of 30 degrees

LMWH(enoxaparin) $1 \mathrm{mg} / \mathrm{kg}$ subcutaneously

if no contraindication

Gastric ulcer prophylaxis

Oral care - Chlorhexidine mouth washes at least 3 times a day

\section{Feeding}

Start feeding after tracheostomy. Continuous drip feeding via the nasogastric tube is best. Energy requirement- $35 \mathrm{kCal} / \mathrm{kg} /$ day (can go up to even $40-45 \mathrm{kCal} / \mathrm{kg} /$ day)

Constipation is a problem.

Add laxatives and fiber to the diet.

Physiotherapy specially to the chest and limbs are important and may need sedation.

Maintain constant communication to keep up the morale of the patient.

Attempt mobilising patient in the $2^{\text {nd }}$ week.

Attempt weaning fromMg in the $3^{\text {rd }}$ week.

Fill the communicable disease surveillance forms for tetanus. 